\title{
Feasibility study of a CHP plant with steam turbine and biomass gasification for tissue paper production
}

\author{
Stefano Frigo ${ }^{a *}$, Roberto Gabbriellib ${ }^{\mathrm{b}}$ Luca Linari ${ }^{\mathrm{c}}$ \\ ${ }^{a}$ Dipartimento di Ingegneria dell'Energia, dei Sistemi, del Territorio e delle Costruzioni-Università di Pisa, Largo L. Lazzarino, Pisa 56126, Italy \\ ${ }^{b}$ Dipartimento di Ingegneria Civile e Industriale - Università di Pisa, Largo L. Lazzarino, Pisa 56126, Italy \\ ${ }^{c}$ TOSCOTEC SPA, Head of Energy \& Environment Dep. - Viale Europa , 55012 Marlia- Lucca Italy
}

\begin{abstract}
In remote areas, such as India, Africa and Southeast Asia, typically not connected to the natural gas distribution network, tissue paper production is currently carried out using a Yankee cylinder and two hot air hoods heated with saturated steam produced in conventional boilers. In this way the drying air is heated at medium temperature, around $160-180^{\circ} \mathrm{C}$, with consequent low levels of dried paper production.

In this context, the present study intends to evaluate the technical and economic feasibility of using a wood biomass fixed bed downdraft gasification plant for the production of syngas to be used as fuel in gas hoods, in order to reach high drying temperatures (around $500{ }^{\circ} \mathrm{C}$ ), comparable with those of the current modern hoods powered with natural gas. Using previously developed calculation codes, an evaluation of energy performance of the paper drying system and of the gasification plant has been performed. The present study also evaluates the possibility of applying a CHP plant, powered by biomass, for the production of steam and electric, this last obtained adopting a steam turbine, thus covering all the electrical and thermal needs of the paper mill.

Results show that, for a paper mill with a production of about $80 \mathrm{t} /$ day of paper, two gasification reactors with a thermal output of about 1.95 $\mathrm{MWt}$, and a consumption of dry biomass of $0.86 \mathrm{t} / \mathrm{h}$, are required. For the steam system, the net electric power needed to meet the needs of the paper mill is about $3100 \mathrm{~kW}$ with a consumption of $4.72 \mathrm{t} / \mathrm{h}$ of moist biomass and a net efficiency of $23.9 \%$.
\end{abstract}

(C) 2018 The Authors. Published by Elsevier Ltd.

This is an open access article under the CC BY-NC-ND license (https://creativecommons.org/licenses/by-nc-nd/4.0/)

Selection and peer-review under responsibility of the scientific committee of the 73rd Conference of the Italian Thermal Machines Engineering Association (ATI 2018).

Keywords: paper production, biomass gasification, CHP, modelling

\section{Introduction}

The tissue industry, especially in last ten years, is showing a fast growing, on global base, with a rate between $3,4 \%$ and $4,2 \%$. The most interesting countries, from growing point of view, are China (main driving force) and Far East countries and also, from percentage point of view, Africa. Table 1 shows some interesting numbers related to tissue demand and growth rate divided by regions $[1,2]$.

\footnotetext{
* Corresponding author. Tel.: +39-050-2217105; fax: +39-050-2217150.

E-mail address: s.frigo@ing.unipi.it
}

1876-6102 ㄷ 2018 The Authors. Published by Elsevier Ltd.

This is an open access article under the CC BY-NC-ND license (https://creativecommons.org/licenses/by-nc-nd/4.0/)

Selection and peer-review under responsibility of the scientific committee of the 73rd Conference of the Italian Thermal Machines

Engineering Association (ATI 2018).

10.1016/j.egypro.2018.08.136 
Table 1. Tissue paper demand and growth rate by region [1].

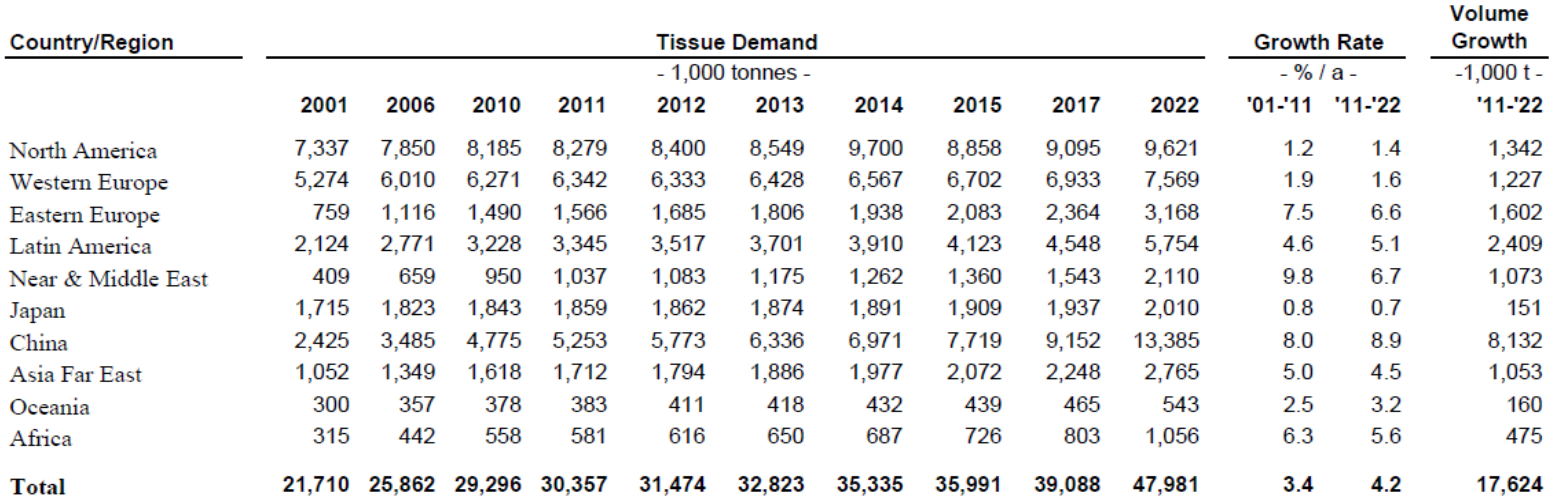

Recent tissue paper mill installations in Far East and China are typically large (paper width 5,4 m or bigger) and medium size (paper width $3.4 \mathrm{~m}$ ) paper machines and very performing (machine speed up to $1800-2000 \mathrm{~m} / \mathrm{min}$ ). The producers in Middle East and Africa install small (up to 2,9-3 m) or medium size paper machines, with an operating speed up to $1000-1600 \mathrm{~m} / \mathrm{min}$.

As a whole, a paper mill is a very energy consuming industry, both electric and thermal. Considering the thermal energy, which is usually the greatest, modern tissue paper technology sees the presence, in the drying section, of a steel (in the past Cast Iron made) steam heated cylinder (the so called "Yankee" cylinder) and high temperature hoods, these last able to produce and to imping, on the paper surface, air at high temperature (up to 500-600 ${ }^{\circ} \mathrm{C}$ ) and velocity (up to $160 \mathrm{~m} / \mathrm{s}$ ). The possibility to reach that high temperature is strictly related to the heating process adopted inside the hood. This means that if conventional heat exchangers (steam heated, 18-20 barg max pressure) are adopted to warm up the air, only temperature in the order of $160-185{ }^{\circ} \mathrm{C}$ can be reached. But if a gas fuel is available for the plant, special burners can be located inside the hood, able to increase the air temperature up to $500-600^{\circ} \mathrm{C}$, with obvious advantages in terms of drying capacity.

The heating fuel is more related to the local availability and, partially, on the base of environmental rules. We can assume that in Europe and North America the most common heating fuels for hoods is natural gas. But in other countries, such as Africa, Far East and China, Diesel oil, heavy oil and coal are used in boilers for steam production, this because natural gas is very expensive and, for the moment, not easily accessible. On the other side, in these last countries, where natural gas is hardly available, a large amount of woody biomass is present.

The aim of this work is to evaluate, technically and economically, the possibility of adopting a supply energy system (electric and thermal) for a tissue paper mill based only on wood biomass utilisation, which sees the presence of a boiler to feed a steam turbine and the Yankee cylinder, with the addition of a gasification section to furnish the appropriate amount of gas for the high temperature hoods.

\section{Combined heat and power plant with steam turbine and biomass gasification for tissue paper production}

The present feasibility study is based on a paper mill that produces tissue paper starting from virgin cellulose. The actual plant utilizes the electricity from the grid while the thermal needs, both for the Yankee cylinder and for the hoods (air temperature up to $\left.180^{\circ} \mathrm{C}\right)$ [3], are satisfied with a steam boiler fueled with heavy oil.

In the proposed plant (see Figure 1) the electricity and the steam for the Yankee cylinder are produced utilizing a steam power plant fed with woody biomass, while a wood gasification plant [4-6] is adopted to furnish the syngas utilized in the high temperature hoods. In particular, the steam for the Yankee is bled from a steam turbine (Figure 2), therefore the plant produces electricity to drive the process equipment and provides the Yankee cylinder with steam.

The steam power plant, based on a superheated Hirn cycle, is composed by a conventional moving grate humid biomass fired combustion chamber, where high pressure superheated steam is produced. The steam expands in a multistage steam turbine whose outlet is condensed in a low temperature condenser using fresh water from a close river. The steam plant is completed by a condenser, a deaerator and a preheater to warm up the boiler feeding water using steam bleedings. The combustion air is preheated in a heat recuperator using the exhaust gas upstream the stack. The Yankee cylinder is fed by another steam bleeding. In the Yankee, the dry saturated steam is partially condensed and then the condensate is separated in a flash tank and mixed with the water from the deaerator.

The high temperature air for the impingement drying is obtained in two suitable burners firing syngas that is produced in two biomass gasification systems (Figure 3). Each of them is composed by an atmospheric downdraft gasifier of chipped virgin biomass and by a cleaning system of the syngas. The wet virgin chipped biomass is dried to $15 \%$ of moisture content (on wet basis) using an equi-current rotating dryer with high temperature air that is produced with a further steam bleeding from the steam power plant. The gasifying agent is air that is preheated by the syngas at the outlet of the gasifier. The fly ash is removed from the syngas in a cyclone in order to avoid fouling in the following heat recuperator and black spots on the paper sheet during production. A suction fan assures the required flux of the gasifying air. So, in the present novel layout, it is possible to produce the impingement air with 
largely higher temperature than in original air hoods where heat exchangers, based on steam utilization, are adopted for the impingement air production.

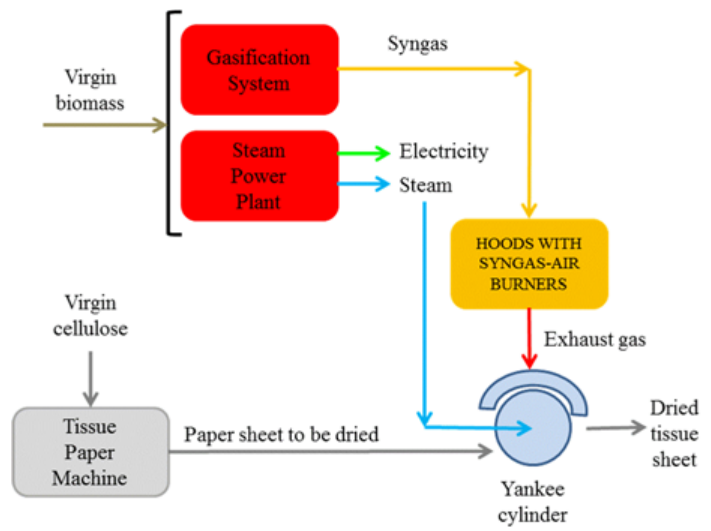

Fig. 1. Overall plant layout of the paper mill integrated with the combined heat and power plant.

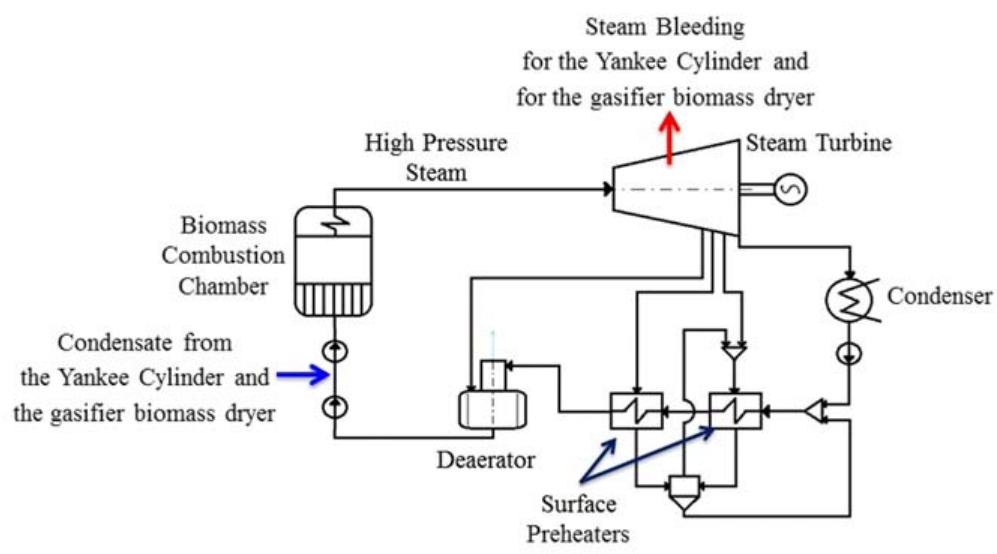

Fig. 2. Steam power plant with steam bleeding for the Yankee cylinder.

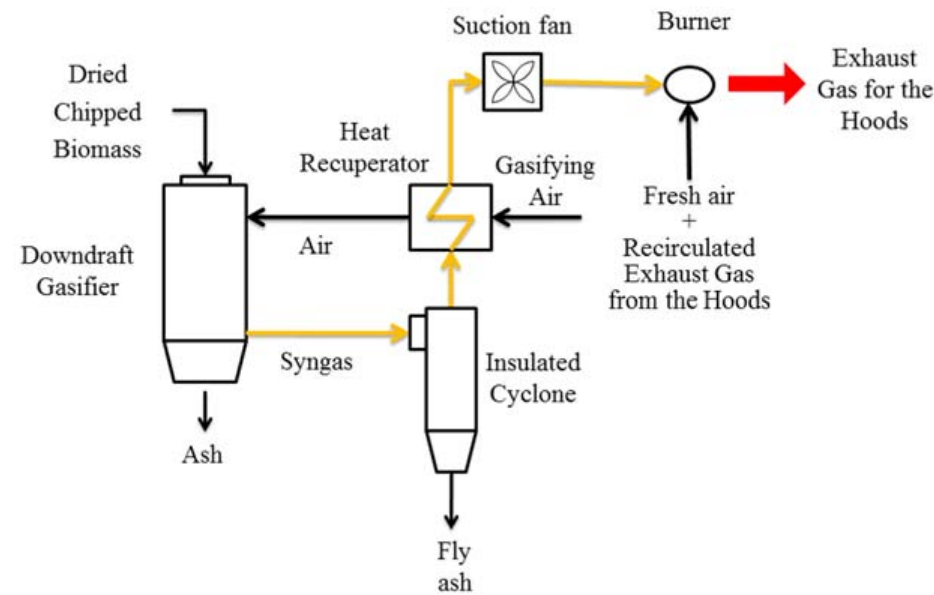

Fig. 3. Biomass gasification system for the syngas production. 


\section{Design of the novel integrated system and assessment of the energy performances}

\subsection{Operative requirements of the paper mill}

The operative requirements of the overall paper mill that have to be satisfied by the integrated combined heat and power plant are the input data for the following design as reported below:

- Yankee cylinder, that is heated by steam bleeding from the turbine:

- thermal drying power: $2250 \mathrm{~kW}_{\text {th }}$

- steam pressure: 17 bar

The steam pressure is reduced in the ejector down to about 10 bar before entering the Yankee.

- air hoods, that are satisfied with syngas from the gasification systems:

- thermal power: $2750 \mathrm{~kW}$ th

- air temperature: $490{ }^{\circ} \mathrm{C}$

- paper mill:

- $\quad$ electric power: $3000 \mathrm{~kW}$

\subsection{Design of the gasification system}

The aim of the gasification analysis was to calculate the biomass requirement of the gasifier, syngas composition and the number of reactors that are necessary to produce the required syngas mass flowrate. The gasification system, based on a downdraft fixed bed reactor, has been designed and its energy performances have been evaluated using a kinetic model developed and implemented in Aspen Plus ${ }^{\circledR}$ V. 9.0 commercial code, whose main features were described in previous works [7-9]. As a whole, the gasifier is divided in ten continuous stirred tank reactors in equicurrent configuration. For each equipment, such as the gasifier, cyclone and suction fan, their specific geometry and performance features have been considered and implemented in the simulation model. The property method of Redlich-Kwong-Soave (RK-Soave) with cubic equation has been selected for the simulation of the conventional components. Simulation results allow to evaluate the gasifier cold gas efficiency (CGE), defined as the ratio between the chemical power output corresponding to the syngas flow and the input chemical power of the dried biomass, the syngas mass flowrate and composition (therefore its LHV). The composition of the biomass that has been considered in the calculation is reported in Table 2. Owing to the syngas mass flowrate required by the high temperature hoods and considering a maximum thermal power of a single gasifier equal to $2.5 \mathrm{MW}$, it is necessary to install two gasifiers. This size can be considered the maximum value for downdraft configuration in order to allow an appropriate gasification process.

The results of the thermodynamic analysis obtained with Aspen Plus for a single reactor are reported below.

- Reactor:

- $\mathrm{CGE}=70 \%$

- biomass mass flow (moisture content equal to $15 \%$ and $\mathrm{LHV}$ equal to $13 \mathrm{MJ} / \mathrm{kg}$ ) $=550 \mathrm{~kg} / \mathrm{h}$

- $\quad$ thermal power input $=1950 \mathrm{~kW}_{\text {th }}$

- gasifying air $=425 \mathrm{~kg} / \mathrm{h}$

- Syngas:

- $\mathrm{LHV}=5800 \mathrm{~kJ} / \mathrm{Nm}^{3}$

- $\quad$ mass flow $=950 \mathrm{~kg} / \mathrm{h}$

- $\quad$ volume composition $($ dry basis $)=22.9 \% \mathrm{CO}, 12.0 \% \mathrm{CO}_{2}, 2.8 \% \mathrm{CH}_{4}, 17.9 \% \mathrm{H}_{2}, 44.4 \% \mathrm{~N}_{2}$

- $\quad$ syngas outlet temperature $=800{ }^{\circ} \mathrm{C}$

In order to obtain the dried biomass required by the two gasification systems, a dryer is adopted. The drying air is heated at $180{ }^{\circ} \mathrm{C}$ using a steam bleeding from the turbine. The main operative features of the dryer are calculated with Aspen Plus and are reported below:

- $\quad$ humid biomass mass flow $=1700 \mathrm{~kg} / \mathrm{h}$

- gross thermal power $=570 \mathrm{~kW}_{\text {th }}$

- drying air $=11 \mathrm{t} / \mathrm{h}$

Table 2. \% Biomass composition (dry basis).

\begin{tabular}{cccccc}
$\mathrm{C}$ & $\mathrm{H}$ & $\mathrm{N}$ & $\mathrm{O}$ & Ash & $\mathrm{PCI}$ \\
\hline$\%$ & $\%$ & $\%$ & $\%$ & $\%$ & $\mathrm{MJ} / \mathrm{kg}$ \\
\hline 48,05 & 6,04 & 0,16 & 43,85 & 1,87 & 17,99
\end{tabular}

\subsection{Design of the steam thermal power plant}

The electric power that is required by the paper mill and by all auxiliaries of the gasification systems is completely produced by the steam power plant. A simulation model of the power plant is constructed with the software GateCycle (Figure 4), where the cogeneration of the thermal power is simulated with specific steam condenser. The size of the power plant has been defined 
iteratively so that the required electric power (see section 3.1) is produced. The operative features of the steam power plant are reported below:

- thermal power of the boiler $=13.1 \mathrm{MW}_{\text {th }}$

- water temperature at the inlet of the boiler $=137^{\circ} \mathrm{C}$

- steam mass flow at the inlet of the steam turbine $=14.4 \mathrm{t} / \mathrm{h}$ at $500{ }^{\circ} \mathrm{C}$ and $100 \mathrm{bar}$

- thermal power of the condenser $=5.0 \mathrm{MW}_{\text {th }}$

- thermal power that is used in the paper mill and in the dryer $=3.0 \mathrm{MW}_{\text {th }}$

- gross electric power: $3125 \mathrm{kWe}$

- net thermodynamic efficiency $=23.9 \%$

- humid biomass mass flow $(50 \%$ moisture content on wet basis $)=4.72 \mathrm{t} / \mathrm{h}$

- overall combustion air $=28 \mathrm{t} / \mathrm{h}$

\subsection{Design of humid biomass storage system}

The humid biomass that is used in the dryer and in the steam boiler is stored in an open air storage building with a protection against weathering. The overall daily consumption of humid biomass is about $154 \mathrm{t}$. The overall storage system requirements have been estimated in at least ten days of autonomy, therefore the amount of woody biomass that has to be stored is about $1540 \mathrm{t}$. The loading of the biomass into the boiler and the dryer is executed with dosing screw conveyors.

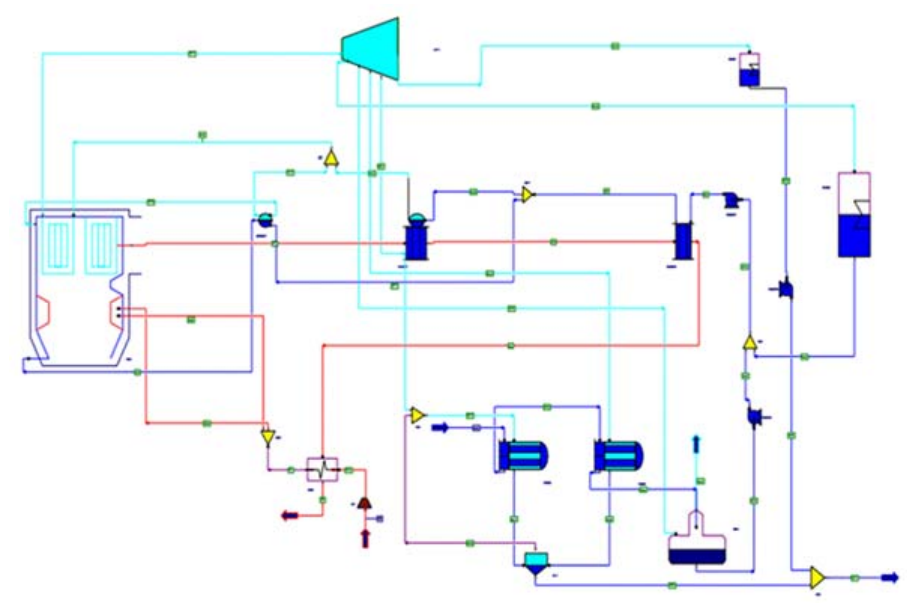

Fig. 4. GateCycle simulation model of the combined heat and power steam plant.

\subsection{Drying of the tissue paper in the Yankee cylinder-hoods system}

As aforementioned, the novel configuration of the drying system for the production of tissue paper sees the presence of a Yankee cylinder and a high temperature hoods, this last of the duosystem in cascade type with two burners and extraction of the exhaust gas from the wet hood outlet [10-12].

The main geometric data of the drying system, which are considered as input data for the calculation, are reported below.

- $\quad$ wrap angle of the wet-end hood $=125^{\circ}$

- $\quad$ wrap angle of the dry-end hood $=125^{\circ}$

- Yankee cylinder diameter $=4572 \mathrm{~mm}$

- steam pressure within the Yankee cylinder $=6$ bar

- width of the sheet on the pope $=2800 \mathrm{~mm}$.

The actual configuration of the drying system, that the novel integrated proposal should substitute, has the following characteristics and performances:

- the hot gas in the hoods is produced in a steam heated heater at $160^{\circ} \mathrm{C}$ and the steam for the hoods and Yankee cylinder is obtained in a heavy oil fired conventional steam boiler;

- the electric demand is completely satisfied acquiring the electricity form the national distribution grid.

- daily production of paper $(95 \%$ of dryness $)=65 \mathrm{t}$

- overall heavy oil consumption $=270 \mathrm{~kg} / \mathrm{h}$

- specific energy consumption $=1270 \mathrm{kWh} / \mathrm{t}$ of paper

The energy performance of the alternative drying system has been evaluated using a custom made simulation code implemented in Matlab language [13], whose main characteristics were presented in a previous paper [14]. Maintaining the same geometric 
features of the drying system (i.e, the same size of the Yankee cylinder and of the air hoods) the simulation with syngas burners gives the following results:

- daily production of paper $(95 \%$ of dryness $)=80 \mathrm{t}$

- grammage of the paper $=18 \mathrm{~g} / \mathrm{m}^{2}$

- air impingement temperature of both hoods $=450{ }^{\circ} \mathrm{C}$

- air impingement velocity $=110 \mathrm{~m} / \mathrm{s}$

- $\quad$ specific energy consumption $=1490 \mathrm{kWh} / \mathrm{t}$ of paper

- specific evaporation rate (referenced to the lateral surface of the Yankee cylinder) $=75 \mathrm{~kg} / \mathrm{m}^{2} \mathrm{~h}$

The simulation has confirmed that the novel configuration of the drying system using syngas burners, for the production of the high temperature gas, assures an increased drying capacity compared to the original steam heated heat hoods.

\section{Profitability analysis of the novel integrated combined heat and power plant}

The net present value and the internal rate of return are evaluated in order to assess the profitability of the installation of the alternative integrated combined heat and power plant in comparison with the actual configuration. So, the differential investment approach is adopted and, consequently, the cost due to the paper mill are not considered with the exception for the syngas fired burners and steam thermal power plant. The investment is supposed to be founded with a long term bank loan. The input data of the economic analysis are summarized below:

$\circ$ electricity $\operatorname{cost}=0.12 € / \mathrm{kWh}$.

- life of the investment $=25$ years

○ rate of interest $=6 \%$

- loan rate of interest $=4 \%$

$\circ$ duration of the loan $=20$ years

○ tax rate $=30 \%$

$\circ$ fiscal amortization $=11$ years

○ cost of cellulose $=650 € / \mathrm{t}$

$\circ$ selling price of the paper $=1050 € / \mathrm{t}$

$\circ$ cost of biomass $=30 € / \mathrm{t}$

○ cost of heavy oil $=400 € / \mathrm{t}$

○ maintenance cost $=4 \%$ of the investment cost

$\circ$ dismantling cost of the ash $=90 € / \mathrm{t}$

$\circ \quad$ annual wage of the operator $=30000 € /$ year

$\circ$ annual hours of operation $=7900 \mathrm{~h} / \mathrm{y}$

○ specific capital cost of the steam thermal power plant $=4000 € / \mathrm{kW}_{\mathrm{e}}$

$\circ$ specific capital cost of the gasification system $=500 € / \mathrm{kW}_{\text {th }}$

The biomass is supplied by own forest and its cost is due to the cut and supplying to the paper mill. The capital expenditures (Capex) of the steam thermal power plant and of the gasification system have been calculated considering their specific plant cost reported above and multiplying it for the net electric power and for chemical power of the input biomass, respectively. In Table 3 the results of the economic comparison are summarized. Thanks to the adoption of the integrated combined heat and power configuration, the increase in the air temperature inside the hoods allows to obtain a large daily production of paper and, consequently, guarantees a greater profitability compared to the actual oil-fired paper mill.

Table 3. Results of the economic analysis.

\begin{tabular}{ccc} 
& Proposed CHP plant & Actual paper mill \\
\hline Capital cost, M€ & 15 & 2.07 \\
\hline Annual operative costs, M€ & 18.5 & 17.0 \\
\hline Annual income from paper selling, M€ & 27.6 & 22.46 \\
\hline Gross annual income, M€ & 9.13 & 5.44 \\
\hline Net annual income, M€ & 5.88 & 3.74 \\
\hline Net present value, M€ & 72.27 & 47.40 \\
\hline Differential net present value, M€ & & \\
\hline IRR of the differential investment, $\%$ & & \\
\end{tabular}

In Figure 5 the dependence of the differential net present value for the two different investments on the rate of interest is reported in order to assess the effect of the risks connected with the investments. In Figure 5 three different values of the cost of cellulose and of the electricity cost are considered in order to assess the sensitivity of the profitability with respect to two of the most important data of the investment analysis. So, pessimistic and optimistic values together with average values are considered. The 
scenarios with the highest cost of the cellulose and the lowest cost of electricity is evidently the most precautionary. Also in this situation, the novel integrated combined heat and power plant appears remunerative in comparison with the original paper mill configuration.

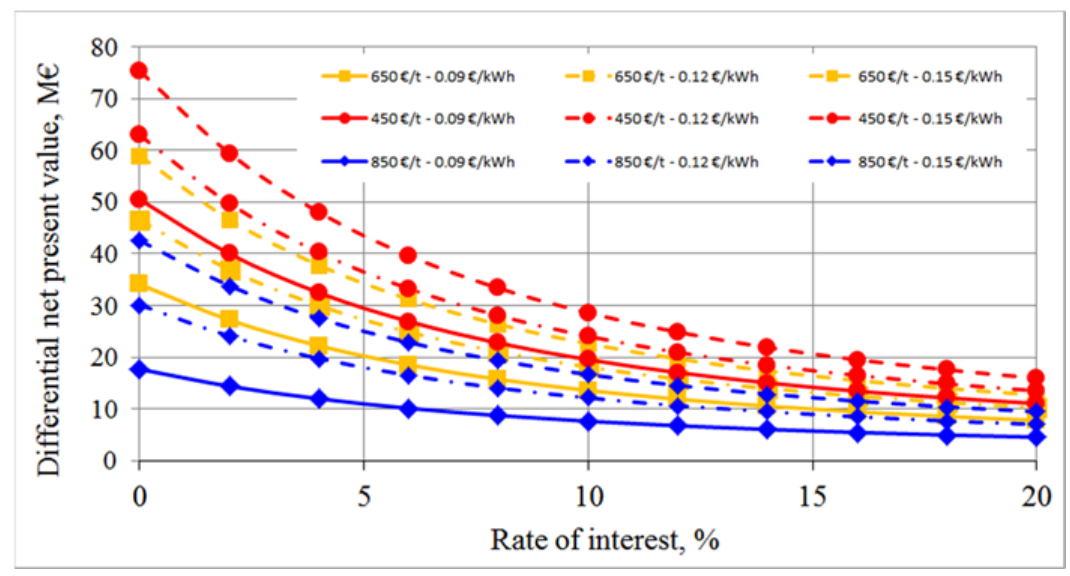

Fig. 5. Economic comparison between the novel configuration and the conventional one.

\section{Conclusions and future remarks}

In this paper the possibility to adopt an extensive exploitation of biomass for the complete satisfaction of the energy demand of a tissue paper mill is assessed. In countries where the supply of the natural gas is not present and biomass resources are widely available, the biomass can be considered a valid energy source for the production of tissue paper, even adopting modern technology for the drying section (high temperature hoods). Considering a paper mill with a daily production of about $80 \mathrm{t} /$ day, it is possible to satisfy its energy demand installing two downdraft gasification systems of $1.95 \mathrm{MW}_{\text {th }}$ and a steam power plant with thermal power input of about $13.1 \mathrm{MW}_{\text {th }}$ and net electric efficiency equal to about $23.9 \%$. The overall combined heat and power system annually requires about $50,700 \mathrm{t}$ of virgin biomass. With respect to a conventional system which exploits heavy oil for the production of steam and uses the grid for the supply of electricity, the increase of the gas temperature in the hoods assures higher daily production of tissue paper (up to $20 \%$ ) and, consequently, higher remunerability of the investment.

\section{References}

[1] RISI Outlook for World Tissue Business Forecast 2013-2016.

[2] Bruce, Janda "Future of Tissue manufacturing to 2021", Smithers Pira www.smitherspira.com.

[3] Mujumdar As. Handbook of industrial drying. third ed. (2006) New York, Marcel Dekker.

[4] Kirubakaran V, Sivaramakrishnan V, Nalini R, Sekar T, Premalatha M, Subramanian P. "A review on gasification of biomass." Renewable and Sustainable Energy Review 13 (2009): 179-186.

[5] Asadullah, Mohammad. "Barriers of commercial power generation using biomass gasification gas: a review." Renewable and Sustainable Energy Review 29 (2014): 201-215

[6] Ahmad, Anis Atikah, Zawawi, Norfadhila Abdullah, Kasim, Farizul Hafiz, Inayat, Abrar, Khasri, Azduwin. “Assessing the gasification performance of biomass: a review on biomass gasification process conditions, optimization and economic evaluation." Renewable and Sustainable Energy Review 53 (2016): 13331347.

[7] Formica, Marco, Frigo, Stefano, Gabbrielli, Roberto. "Development of a new steady state zero-dimensional simulation model for woody biomass gasification in a full scale plant.” Energy Conversion and Management 120 (2016): 358-369.

[8] Frigo, Stefano, Gabbrielli, Roberto, Seggiani, Maurizia. "Comparison between equilibrium and kinetic models with aspen plus for a full scale biomass downdraft gasifier." Proceedings of 25 th European Biomass Conference \& Exhibition EUBCE 2017, 12-15 June 2017, Stockholm, Sweden.

[9] Frigo, Stefano, Gabbrielli, Roberto, Gallo, Maria Grazia, Sansone, Franco, Seggiani, Maurizia. "Experimental and numerical approach to improve the performance of a small CHP wood gasification plant." Proceedings of $26^{\text {th }}$ European Biomass Conference \& Exhibition EUBCE 2018, 14-17 May 2018, Copenhagen, Denmark.

[10] Karlsson Markku. Papermaking Part 2, Drying, IX volume in the Papermaking Science and Technology series, Tappi.

[11]Heikkila, Pertti, Milosavljevic, Nenad. "Investigation of impingement heat transfer coefficient at high temperatures." Drying Technology 20 (2002): $211-222$.

[12] Heikkila, Pertti, Milosavljevic, Nenad. "Influence of impingement temperature and nozzle geometry on heat Transfer-Experimental and theoretical analysis." Drying Technology 21 (2003): 1957-1968.

[13] MATLAB. MATLAB - the language of technical computing. 2012.

[14]Di Marco, Paolo, Frigo, Stefano, Gabbrielli, Roberto, Pecchia, Stefano. "Mathematical modelling and energy performance assessment of air impingement drying systems for the production of tissue paper." Energy 114 (2016): 201-213. 